The University of San Francisco

USF Scholarship: a digital repository @ Gleeson Library |

Geschke Center

Economics

College of Arts and Sciences

2011

\title{
Social Networks, Neighborhood Effects, and Credit Access: Evidence from Rural Guatemala
}

Bruce Wydick

University of San Francisco, wydick@lucas.usfca.edu

Harmony Karp Hayes

Sarah Hilliker Kempf

Follow this and additional works at: http://repository.usfca.edu/econ

Part of the Economics Commons

\section{Recommended Citation}

Bruce Wydick, Harmony Karp Hayes, Sarah Hilliker Kempf. Social Networks, Neighborhood Effects, and Credit Access: Evidence from Rural Guatemala. World Development. Volume 39, Issue 6, June 2011, Pages 974-982. DOI: 10.1016/j.worlddev.2009.10.015

This Article is brought to you for free and open access by the College of Arts and Sciences at USF Scholarship: a digital repository @ Gleeson Library | Geschke Center. It has been accepted for inclusion in Economics by an authorized administrator of USF Scholarship: a digital repository @ Gleeson Library $\mid$ Geschke Center. For more information, please contact repository@usfca.edu. 


\title{
Social Networks, Neighborhood Effects, and Credit Access: Evidence from Rural Guatemala
}

\author{
JEL Classifications: 012, O16, D83, L14
}

February 2009

\begin{abstract}
Bruce Wydick, Harmony Karp Hayes, and Sarah Hilliker Kempf
Abstract: We measure the extent to which social networks determine sources of credit from a survey of 465 households in western Guatemala. We estimate correlated, contextual and endogenous effects of networks at the neighborhood, church, and village levels, finding that church networks display endogenous effects in credit access. We calculate an elasticity of social imitation (ESI) indicating if the percentage of people accessing microfinance in a church network doubles, the probability of an individual household accessing microfinance increases by 14.1 percent, a magnitude similar to our estimated ESIs for televisions and cell phones within church and neighbor networks.
\end{abstract}

\author{
Wydick: Department of Economics \\ University of San Francisco \\ 2130 Fulton St. \\ San Francisco, CA 94117 \\ 415-422-5863 \\ wydick@usfca.edu \\ Hayes: The San Francisco Foundation \\ 225 Bush Street, Suite 500 \\ San Francisco, CA 94104 \\ 415-733-8558 \\ bk.k@sff.org \\ Kempf: University of California, San Francisco \\ 1701 Divisadero St, Box 0316 \\ San Francisco, CA 94143 \\ 415-828-8275 \\ sarabbkempf@gmail.com
}

The authors wish to thank William Brock, Bryan Graham, David Levine, Charles Manski, Craig McIntosh, Edward Miguel, and seminar participants at the Conference on Microfinance, University of Groningen, the Netherlands, the University of California at Santa Barbara, and the 2006 Pacific Conference for Development Economics. Grant funding from BASIS/USAID and the McCarthy Foundation is gratefully acknowledged. 


\section{Introduction}

An emerging literature in economics has revealed the importance of social networks in household decision-making (Kremer and Miguel, 2003; Conley and Udry, 2008; Munshi and Myeaux, 2006). At the same time, it is well-recognized that personal relationships play a large role in credit access, particularly in developing countries (Basu, 1984; Udry, 1994; Fafchamps, 2000; Okten and Osili, 2004). Our research brings these two strands of literature together to ascertain the influence, and the nature of the influence, that social networks have on credit access. Because there remains a gap in the literature in our understanding of why certain households take microfinance loans and others do not, we are particularly interested in the influence that social networks may have on microfinance borrowing.

The data used in our study comes from a survey of 465 households located in five proximate villages in the western highlands of Guatemala. We find that microfinance borrowing by households is positively related with the level of education and negatively related to wealth level in both a household's village and church network. We also discover that while geographical networks appear to significantly influence household decision-making in the adoption of consumer technologies such as cell phones and televisions, church networks appear to play the predominant role in determining household sources of credit. Moreover, we calculate an elasticity of social imitation for microfinance and find point estimates for this elasticity very close to that for formal loans and moneylender credit. For each of these three types of credit, a doubling of the number of the households in a church network with a given type of credit is associated with an approximately $15 \%$ increase in the probability of a household holding that particular type of credit, controlling for other factors that influence behavioral similarities. We argue that the strong peer effects found in church networks make sense in the context of the tremendous political, economic, and religious changes that have occurred in Guatemala's recent history, where the 36-year civil war eroded family and neighbor relationships, and the evangelical protestant churches played a major role in filling the gap of social support. 
Manski (1995) suggests three basic categories of reasons why we might observe behavioral imitation within social networks. The first of these he calls a correlated effect, in which individuals in the same group tend to behave similarly because they face similar environments or by their characteristics they self-select into a given social network. For example, rough terrain around a village may render car transportation difficult, so that many people ride bikes. The second category he identifies is a contextual effect, in which the propensity for a given type of behavior varies with the background characteristics of the people in a social network. For example, widespread poverty within a village may preclude the level of economic prosperity necessary to provide individual households the financial means for purchasing bicycles. The third category Manski labels an endogenous effect, in which for example the propensity for owning a bicycle literally varies with prevalence of bicycle ownership in the particular reference group. When endogenous effects exist, genuine imitation occurs within a network, but these endogenous effects can take many forms.

Young (1998) classifies three potential types of endogenous effects. Endogenous effects can be of pure conformity in which fashion or fad dictate behavior within a particular network. A girl rides a bicycle because she wants to "fit in" with her peers, who all ride bicycles. A second motive may be instrumental conformity: people in a village all ride the same type of bicycle because it makes it easier for each to obtain spare parts. A third type of endogenous effect may be brought about through informational conformity: A boy sees another boy in his social network enjoying a bicycle. This signals to him that riding a bicycle yields a higher level of utility than he otherwise believed, making him want one himself. Ellison and Fudenberg (1993) refer to this as "word of mouth" learning, and in the context of limited information, behavior within a network may converge toward uniformity.

Some of these explanations are more likely than others in explaining similar sources of credit within a network. Correlated effects could be present if bad weather hits a given area, forcing everyone to borrow from an agricultural credit cooperative created by the state to aid struggling farmers. We could observe contextual effects if people with different levels of income 
or education tend to seek similar sources of credit, and education levels are correlated within networks. Endogenous effects in borrowing seem unlikely to occur through a desire for pure conformity. However, networks may play a number of roles with credit that are related to a combination of informational and instrumental conformity.

The following are a few examples. Networks may be a source of information: An individual A may expose a friend in his network, $B$, to opportunities of which B was previously unaware, for example that $\mathrm{C}$ offers a superior credit contract than other opportunities available to $\mathrm{B}$. Second, networks can help serve a screening function: A may introduce $\mathrm{B}$ to his lender, $\mathrm{C}$. If $\mathrm{C}$ trusts $\mathrm{A}$, and knows that $\mathrm{A}$ has an interest in maintaining this trust, then $\mathrm{C}$ should take A's recommendation of B as a strong signal of B's reliability. Third, reputation within networks may serve as a kind of social collateral for loans, producing a kind of instrumental conformity in which borrowers access loans from the same lenders in a network: C may offer a loan to B partly based on B's reputational collateral that also involves another of his borrowers, A, a merchant who also deals regularly with B. If B's repayment performance is common knowledge within the network, B's failure to repay may send a negative signal to A about B's trustworthiness. Knowing that B wants to maintain his reputation with $\mathrm{A}$ (as well as perhaps with $\mathrm{C}$ ), $\mathrm{C}$ may be willing to grant loans to $\mathrm{B}$ as well as to A. Our work on sources of credit is closely related to several recent papers on other kinds of behavioral choices influenced by networks within developing countries. Kremer and Miguel (2003) utilize a randomized implementation of a school-based de-worming program in Kenya to study the impact of social networks on the adoption of worm-treatment drugs. They interviewed children and parents of the children who participated in the de-worming program, obtaining information on their social networks. Their survey focused on the five individuals they spoke with most frequently, relatives with whom they had frequent social interaction, and individuals with whom they discussed child health issues. But because many of the early subjects had unpleasant experiences with the treatment, Kremer and Miguel find that children who were linked in a social 
network to those who had already taken the drugs were less likely to take the treatment than other children. Specifically, every social link by parents with other parents of children exposed to the treatment is associated with a 3.1 percentage point lower likelihood of a child taking the treatment. A social link between teenagers reduced the probability of receiving the treatment by 2.8 percentage points, while direct links between small children predictably displayed no significant effect on adoption.

Conley and Udry $(2001,2008)$ study pineapple farmers in Ghana, analyzing optimal application of fertilizer to their crop. Because pineapple in this region was a new export crop, many farmers were still learning proper cultivation techniques. Detailed information was collected on "informational neighbors," farmers who talked to one another about farming practices. They find convincing evidence of social learning among their networks of pineapple farmers, notably that a given farmer is likely to adjust his fertilizer away from the levels of information neighbors who had realized lower than expected pineapple profits, and toward that of successful information neighbors. Furthermore Conley and Udry find that inexperienced pineapple farmers in their survey rely on information from their neighbors to a greater extent than experienced pineapple farmers, and that the behavior of the experienced farmers was imitated more frequently than inexperienced ones. Their earlier work also shows that when information is incomplete and travels through networks, farmers who keep track of observations over a longer period of time will benefit from optimal learning.

A third paper related to our research is Munshi and Myaux (2006), which examines neighborhood effects in contraceptive use in Bangladesh. During the late 1970s, an intensive family planning program was launched that provided both free contraceptives and free visits by community health workers to 144,000 households. The striking result from their study is the effect of religious ties on the pattern of contraceptive adoption within villages. Contraceptive adoption varied considerably between religious groups in the same village. The behavior of individual women was 
strongly responsive to the prevalence of contraceptive use by other women within their own religious group (either Hindu or Muslim), but unresponsive to the prevalence of contraceptive use by others. Even after partitioning their sample of women across other variables, such as age and education, the authors find endogenous effects in the adoption of contraceptives between groups. For example, illiterate women were influenced not only by other illiterate women, but by literate women, and even vice-versa. Munshi and Myaux conclude that the origin of these patterns lies in the purda, a section of Islamic law that severely restricts young married women to socializing only among women of the same religious group. They interpret the results as a desire for social conformity among this group of women.

The contrast in the three studies is interesting. While Kremer and Miguel (2003) and Conley and Udry (2008) reveal evidence of informational conformity within networks, Munshi and Myaux's study on contraception appears to reveal imitation in networks based on pure social conformity. In this respect our study most closely resembles the first two studies, where we attempt to identify endogenous effects that are unlikely to be due to a desire for pure social conformity, but rather for specific issues related to the adverse selection and moral hazards that surround credit transactions.

The implications of our work may have a particular bearing on understanding the diffusion of microfinance as a source of credit access in developing countries. While a privileged few households in developing countries are able to access formal sources of credit, the vast majority borrow from informal sources, such as moneylenders, friends, and extended family. For many households, the introduction of microfinance represents a superior form of credit access, where transaction costs are significantly lower than formal borrowing, and interest rates are significantly lower than informal borrowing. Yet the potential benefits microfinance may bring over existing types of credit may not be immediately or equally recognized within a population. To date, over 133 million households in developing countries have accessed microfinance (Microcredit Summit, 
2007). But in each of these instances, a microfinance loan represents the intersection between an opportunity and a choice of a household to participate; the introduction of a new development program or technology into a particular region is clearly a necessary but insufficient condition for adoption. A better understanding of the influence of social networks on credit access may help to facilitate the introduction of potentially welfare-enhancing initiatives such as microfinance, just as it does in the diffusion of new technologies that offer potential improvements in worker productivity, education, and health.

The next section of our paper describes geographical location and nature of our field survey. Section III presents our empirical model and estimations. Section IV concludes.

\section{Field Research}

Our field survey was carried out from June through August of 2004 in the department (province) of Sololá located in the western highlands of Guatemala. The region is predominately populated with indigenous Quiché and Tzutujil people of Mayan decent living in small rural villages. Household surveys were administered to 465 households in five different villages ranging from the Atitlán lakeshore to the Pan-American highway. Our villages included San Juan Atitlán (107), Santa Clara (126), Tzucubal (87), Cruz B (50), and Argueta (95) as shown in Figure 1. While some of the villages were located within a few miles of one another, the nature of interaction in rural Guatemala is that people from different villages have little social contact with one another.

(Insert Figure 1 here)

Some historical background about our study area is important to interpreting our empirical work. The Sololá province, within which our villages are located, formed part of the theater in which a long civil war was fought in Guatemala from 1960 through 1996, resulting in approximately 200,000 civilian deaths. ${ }^{1}$ During this period, many Guatemalans in the Sololá province were forced to choose between membership in the guerrilla movements or in the civil patrols. Moreover, instances of 
betrayal within villages were common, where false accusations of guerrilla involvement resulted in the disappearances and executions of many innocent victims. As a result, households often looked to an inward circle of trusted relationships. These relationships commonly formed around the budding churches that were part of an indigenous evangelical movement within the country, during which the percentage of evangelicals increased over a few decades from a small percent to over 40 percent (Freston, 2001). The rise of evangelical Protestantism in Latin America has been attributed to the evangelical church's focus on personal salvation, the alleviation of injustice, poverty and misery in the afterlife, support in coping with alcoholism, the spread of literacy, and the desire for economic gain (Garrard-Burnett, 2000). This message is especially attractive to a people plagued by poverty, alcoholism and violence. In the Sololá province, the percentage of evangelicals is even higher than most other areas in Guatemala (53\% in our sample), ranging from 38\% to 66\% in our five villages.

In our survey, we conducted interviews with village leaders to review general information about the village and gain an orientation of its layout. In most cases, pre-existing maps of the villages were used to assign numbers to each household. Within each village, a smaller neighborhood area, generally encompassing approximately one-fourth to one-half of the village, was randomly selected for survey and a blanket approach was implemented to cover every household in the selected area. ${ }^{2}$ With the aid of local guides who acted as liaisons and translators when only local Mayan dialects were spoken, door-to-door interviews were conducted simultaneously by two research teams. GPS coordinates were taken at each household to ensure an exact address for possible follow-up research and to capture information used to measure geographical neighborhood effects.

The survey was centered on obtaining general household information, such as education, ownership of different assets (land and housing), membership in churches, and participation in village committees. We also asked questions about household ownership of consumer goods, particularly bicycles, televisions, and cell phones. Ownership of bicycles within villages ranged 
between 12.2 and 67.4\%, televisions between 30.1 and $75.8 \%$, and cell phones between 2.4 and $18.0 \%$. We asked our households if they had a current loan, and if so whether it was an informal loan (from family, friends, or a local moneylender), a microfinance loan (from one of several microfinance institutions operating in the area), or a formal bank loan (from either a private, or state-sponsored bank). The percentage of households with informal loans ranged from 2.6 to $13.4 \%$ between villages, microfinance from 19.2 to $31.5 \%$, and formal bank credit from 1.9 to $9.6 \%$. Summary statistics on these and other variables from each of the five villages are given in Table 1.

(Insert Table 1 here)

\section{Estimation Strategy and Estimations}

\section{A. Empirical Model}

Upon considering the likely sources of networks that would be relevant to credit decisions, we considered the exploration of peer effects in three reference groups: 1) the entire sample of houses surveyed in the village; 2) households' immediate geographical neighborhoods; and 3) the households' church membership. For the village effect on each household, we calculated $\frac{1}{n} \sum_{i=1}^{n} y_{i j v}=\bar{y}_{j v}$, or the mean of a given behavior $j$ among the $n$ members of a household's village $v$, where $y_{i j v} \in\{0,1\}$. To measure effects from geographical neighbors weighted by proximity, we use a gravity equation, equal to $\sum_{\sim i=1}^{n} \frac{1}{d_{\sim i}^{2}} y_{\sim i j v}$, which heavily weights the behavior $j$ of household $i$ s closest neighbors $(\sim i)$ in $i$ s village $v$. To examine the influence of those in household $i$ s church $c$, we obtain the mean of behavior $j$ observed by other $m$ households that attend household $i$ s church $(\sim i)$, or $\frac{1}{m} \sum_{\sim i=1}^{m} y_{\sim i j c}=\bar{y}_{j c}$.

We seek to estimate the following equation first suggested by Manski $(1993,1995)$ :

$$
E\left(y_{i j k} \mid x_{k}, w_{i}\right)=\alpha+E\left(y_{j k} \mid x_{k}\right)^{\prime} \beta+E\left(w_{k} \mid x_{k}\right)^{\prime} \gamma+x_{i}^{\prime} \delta+w_{i}^{\prime} \lambda+\varepsilon_{i}
$$


where $y_{i j k}$ is the probability of a given discrete behavior $j$ (equal to 0 or 1 ) by household $i$ in network $k, x_{k}$ is $i$ s network one of our three reference groups (village, neighbor, or church), $w_{i}$ is household $i$ s socio-economic status, and $\beta, \gamma, \delta$, and $\lambda$ are parameter vectors, and $\varepsilon_{i}$ an error term. Here, if $\beta \neq 0$ there are endogenous effects, if $\gamma \neq 0$, there are contextual effects, and if $\delta \neq 0$, there are correlated effects. The parameter $\lambda$ measures the direct effect of socioeconomic variables on the expectation of $y$.

As shown in Manski (1995), the model is unable to be estimated using linear estimation techniques due to perfect co-linearity among the independent variables, the basis of the wellknown "reflection problem". However, as demonstrated by Brock and Durlauf (2002, THEOREM 2), Manski's result is specific to a class of linear estimators, such that the above equation is estimable in the context of non-linear estimators, e.g. logit or multinomial logit.

Nevertheless, in estimating equation (1) one must continue to be careful with issues of multicolinearity. A simple example illustrates the problem: Suppose one seeks to analyze a given variable at the village level and there are three villages with membership in the villages given by dummy variables $x_{1}, x_{2}$, and $x_{3}$. Average wealth in each village is given by $\bar{w}_{1}, \bar{w}_{2}$, and $\bar{w}_{3}$, and we also include the independent variable $E\left(w_{k} \mid x_{k}\right)$ given in (1). Even after omitting the dummy for the third village in the standard fashion, a problem remains that $E\left(w_{k} \mid x_{k}\right)-c-\bar{w}_{1} x_{1}-\bar{w}_{2} x_{2}=0$, i.e. that this subset of the independent variables is collinear. For example, suppose that the average wealth index in village 1 and 2 is 0.43 and 0.25 , respectively. This yields a scenario in which $E\left(w_{k} \mid x_{k}\right)-0.30-0.13 x_{1}+0.05 x_{2}=0$, i.e. a subset of the right-hand-side variables are a linear function of one another.

Our estimations make some important assumptions in addressing this issue. In our church network estimations we do not include dummy variables for every church, but rather for type of church, in particular evangelical or Catholic. This implicitly assumes that any correlated effects may 
be different between the two types of churches, but are similar within the two basic types of churches. We are comfortable with this assumption since there are strong similarities between Catholic churches in the study area and strong similarities between evangelical churches (nearly all are Pentecostal or closely related), but substantial differences between the two.

In our estimations of peer effects at the village level, we address the multicollinearity issue by using village fixed-effects in some estimations in which we focus on the influence of networks at the neighbor and church levels, while in other estimations we include village networks without using village-level fixed effects. In the latter estimations, coefficients on the mean values for the dependent variable within a village must be interpreted as representing a combination of endogenous and correlated effects.

Geographical neighbor networks are obviously different for every household, making it impossible in any respect to establish a correlated effect for example by, say, including a dummy variable for every household location. Thus our estimations assume that any significant correlated effects that operate through geographical neighborhoods are accounted for by our variables that directly account for socioeconomic differences between households, and that contextual effects are accounted for by differences in the socioeconomic attributes of household $i$ s geographical neighbors. If they do not, then our coefficients on endogenous effects for geographical neighbors may also include some correlated effects.

We begin our estimations by examining peer effects on household purchase and adoption of three relatively new consumer goods in rural Guatemala: televisions, bicycles, and cellular phones. We use these as a benchmark of comparison for understanding the magnitude of peer effects for different types of credit, yet we find the peer effects uncovered in the adoption of these consumer goods to be interesting in themselves. The villages in our sample were electrified at different times within the last two to three decades. As a result, televisions are a relatively new commodity in comparison with developed countries. Most bicycles in the area are mountain 
bikes, which became a rapidly adopted technology in rural Guatemala following their innovation in the United States during the early 1980s. Mountain bikes allow for rapid transportation over bumpy roads and paths, and are cheaper than either automobiles or horses. In the late 1990s, several mobile phone companies operating in Guatemala began to install a network of cellular towers that blanketed areas with coverage previously untouched by land lines. ${ }^{3}$ Many of these companies quickly offered prepaid phone cards allowing Guatemalans without previous landline access to make domestic calls for 1 quetzal (13 cents) or less per minute. The number of households using cell phones increased rapidly, such that by the time of our 2004 survey nearly $10 \%$ of the rural households in our sample were using cell phones.

\section{B. Empirical Results}

Our empirical approach is to first estimate the effect of socioeconomic variables on the adoption of the new consumer technologies as well as on credit access. Thus we performed a simple logit estimation on cell phone, television, and bicycle ownership using years of formal education, age, a wealth proxy (based on an index of asset ownership that excludes the dependent variable), a dummy variable equal to one if the household head was a member of a village committee, and a dummy variable for evangelical household (as opposed to Catholic). With respect to space constraints, we do not include these regressions here, but the results are straightforward: education is significant at the $95^{\text {th }}$ percent level of confidence for all three consumer goods, and wealth is significant at the $99^{\text {th }}$ percent level for all three. Committee membership is significant at the $95^{\text {th }}$ percent level for cell phones. In all other cases, variables display insignificant direct effects.

For our estimations on credit source, we performed multinomial logit estimations with the dependent variable equal to either "no current loan" (our base category), "informal loan," "microfinance loan," or "formal bank loan." In these estimations, higher levels of education and wealth were significant at the $95^{\text {th }}$ percent level for accessing bank and microfinance credit, but 
(not surprisingly) insignificant for informal credit. Committee membership was significant at no less than the 90 percent level for all three types of credit.

These preliminary estimations are relevant because by (1) we would expect to find contextual effects when the mean of these directly significant socioeconomic variables (wealth, education, and leadership) varies between household networks. Hence in our final estimations, we include the mean of directly significant socioeconomic variables within household $i$ 's network $k$, or $E\left(w_{s} \mid x_{k}\right)$, excluding household $i$ from the computation. (Because of the relative scarcity of community leaders within the sample, we do not include this mean for each network.)

The results of our estimations for peer effects on ownership of cell phones, televisions, and bicycles are given in Table 2. The independent variables are presented in a way that separates endogenous, contextual, correlated, and direct effects, with the aforementioned caveats. In the first three columns of Table 2, we use a standard logit estimation on equation (1), where again we find that the results show education and wealth to be strongly associated with ownership of each of the goods. A calculation of the marginal effects from the logit coefficients reported in columns 1, 2, and 3 in Table 2 indicates that a one-standard-deviation increase in the household wealth index increases the probability of cell phone ownership by 3.5 percentage points $(\bar{x}=9.3 \%)$, television ownership by 28.9 percentage points $(\bar{x}=49.4 \%)$, and bicycle ownership by 14.1 percentage points $(\bar{x}=$ $33.7 \%$ ). A sixth-grade education increases the probability of cell phone ownership (over no formal education) by 1.8 percentage points, television ownership by 16.6 percentage points, and bicycle ownership by 9.6 percentage points. These estimates remain virtually the same in our fixed-effect estimations in Columns 4, 5, and 6.

We uncover little evidence of contextual effects for any of the consumer goods, especially at the church and village level. Average village wealth is significant in all three estimations in Columns 1, 2, and 3, but carries the unexpected sign for cell phone and television. For bicycles, the positive and significant sign on "Average wealth in village" and "Percent bicycle ownership in village" is likely 
to be picking up correlated effects due to differential village terrain due to the absence of village dummies, and because of the inconsistency of the signs of the village-level variables, we are hesitant to attribute the positive sign on bicycles to endogenous or contextual effects.

(Insert Table 2 here)

We are more confident in the estimations using fixed-effects at the village level in Columns 4, 5, and 6 in Table 2. Here we find evidence of endogenous effects for cell phone and television ownership among geographical neighbors at the 95 and 99 percent levels of confidence, respectively. We do not find evidence of geographical neighborhood effects for bicycles. For cell phones, endogenous effects at the neighborhood level are likely to occur as a result of informational conformity: people become convinced of the usefulness of cell phones by observing their neighbors' use of them, finding out how to purchase and use calling cards, and so forth. For televisions, the neighborhood-level endogenous effect is most likely a hybrid of Young's (1998) "pure" and "instrumental" conformity, where households purchase a television in order to follow programs, such as the popular Latin American novelas (soap operas) and/or soccer matches, that are closely tracked and the subject of much discussion among friends and neighbors.

These estimations on the consumer goods can be compared with our multinomial logit estimations on credit source found in Table 3. In these estimations, education and wealth continue to exert a direct influence on the type of credit accessed by a household. They are both positively associated with formal bank and microfinance borrowing and either insignificantly or negatively related to informal borrowing. Microfinance borrowing is also significantly associated with community leadership. As seen in Column 2, but especially in the village fixed-effect estimations in Column 5, evangelicals also appear to be more likely to access microfinance. Though some of the microfinance institutions in these areas are faithbased, they explicitly display no preference for borrowers based on religion, thus making the result more likely a demand-side rather than supply-side phenomenon. Age of household head 
has a significant negative association with formal bank loans, while statistically insignificant

point estimates indicate a negative relationship to microfinance and a positive association with informal loans.

(Insert Table 3 here)

Table 3 also yields some evidence of contextual effects, especially for microfinance.

Education is correlated with increased access to microfinance, and even controlling for individual household-level education, as average education levels increase within a village, the probability of a household having a microfinance loan increases. Marginal effects show that being in a village where the average level of education is one grade higher $(\bar{x}=2.66$ years $)$ increases the probability of microfinance borrowing by 13.7 percentage points. In contrast, an additional year of education decreases the probability of informal borrowing by 4.8 percentage points. In general, both formal and informal borrowing appears to be accentuated when households are members of "wealthier" (less poor) churches and villages, and microfinance is more likely when households are members of more educated churches and villages. Though some of these coefficients do not carry statistical significance, the pattern is manifest.

The most interesting result of the credit source estimations in Table 3 is the presence of endogenous effects in credit access. Some endogenous effects appear to exist at the neighborhood level, especially in informal borrowing. Controlling for other factors, having geographical neighbors with informal credit makes it more likely that an individual household also has informal credit. But the endogenous effects in Table 3 operate primarily within church networks. In both the full estimation of equation (1) in Columns 1-3 and in the village fixed-effects estimation in Columns 4-6, a higher fraction of fellow church members with a given type of credit (bank, microfinance, or informal) yields a higher probability of the individual household having the same specific type of credit. Not surprisingly, the magnitude of the effect is strongest for informal credit, where close relationships are likely to be most important, but it is statistically significant for all types of credit, at 
the $99^{\text {th }}$ percent confidence level in the fixed-effect estimations. While there are some cross-effects from one type of credit to the likelihood of a household accessing a different type, a clear pattern remains in the data with peer effects remaining strongest within a single type of credit.

The immediate question that arises from this result surrounds the possibility of unobservable correlates that would indicate the presence of endogenous effects, but be a result of other factors. One possibility might occur if microfinance borrowing groups were to cluster within churches, but we only saw evidence of individual microfinance lending in villages. We found no evidence that microfinance institutions were using churches to recruit members; moreover, this would fail to explain the clustering of formal bank borrowing and informal lending in churches. It is tempting to argue also that the results could arise from a kind of "Protestant Ethic" phenomenon that governs a self-selection of highly motivated entrepreneurs into certain churches. If our dependent variable were entrepreneurial activity, this would indeed seem possible, yet even so it would likely be identified by our evangelical dummy variable. However, especially in our rural Guatemalan context, it seems unlikely that (controlling for wealth, education, and other factors) entrepreneurs would self-select into churches based on credit access, moreover by specific type of credit access.

Another possibility is that it is through networks of friendship rather than church membership per se that credit relationships operate. We actually view this as quite plausible, if not probable, and it may very well be true in light of the aforementioned political and religious changes in the recent history of Guatemala, in which the rural churches have come to form the hub of a household's network of close relationships. Some of these relationships may have existed prior to common church membership, with others forming as a result of church membership. In a context where the development of human capital and financial assets has been severely stunted, these social relationships appear to play a key role in access to information about financial opportunities. Given the level of accentuated trust that exists within the churches, the most plausible explanation for 
endogenous effects at the church network level relates to the well-understood asymmetric information issues in credit markets, such that within churches credit information circulates regarding credit opportunities, informal screening of borrowers takes place that mitigates problems of adverse selection, and reputational capital within the church helps mitigate problems of moral hazard. Though it is outside of the focus of our empirical work to pin down the precise nature of the endogenous effect, it is most probable that our finding is capturing the often-observed phenomena of credit operating through friendship and other kinds of trust networks, such as illustrated in McMillan and Woodruff (1999), Woolcock and Narayan (2000), Fafchamps (2002), and Okten and Osili (2004).

\section{Elasticity of Social Imitation}

How do the magnitudes of peer effects compare between credit and other possible foci of imitation such as consumer goods? We find that they are surprisingly similar. For each of our consumer goods and sources of credit we calculate an Elasticity of Social Imitation (ESI). In symbols, let $\varepsilon_{S I}=\frac{\% \Delta p r o b(\text { behavior } j \text { by household } i)}{\% \Delta \text { behavior } j \text { in i's network } k}=\frac{d y_{i j}}{d x_{j k}} \cdot \frac{x_{j k}}{y_{j}}$, where the first fraction in the expression is the estimated marginal effect derived from the estimations in Tables 2 and $3, x_{j k}$ is the (potentially) weighted mean of behavior $j$ within a network $k,{ }^{4}$ and $y_{j}$ is the mean of behavior $j$ in the overall sample. The ESI measures the percentage change in the likelihood of a behavior with respect to a percentage change in the prevalence of that behavior within a network, providing a common measure of social imitation.

As seen in Table 4, our estimations yield ESIs on our endogenous effects for credit that are similar in magnitude to those that we estimate for the consumer goods. While point estimates on ESIs for cell phone and television ownership in church and neighborhood networks range from 0.0954 to 0.255 , our estimated ESIs for bank credit (0.179), microfinance (0.141), and informal credit 
(0.167) land right in the middle of this range, and moreover are strikingly similar in magnitude to one another. Point estimates of the ESI for microfinance and informal credit in neighborhood networks are about one-third the magnitude of their ESI within church networks. ${ }^{5}$ The magnitudes of these elasticities of social imitation appear reasonable to us: essentially they say that if the percentage of peers with a given type of credit in a closely knit social network doubles, the likelihood of an individual accessing that specific type of credit increases by about $15 \%$.

(Insert Table 4 here)

From estimated elasticities of social imitation, one can then compute a social imitation multiplier, which gives the equilibrium behavior within a group given the exogenous adoption of that behavior by some fraction $X$ within a network. For any given $\varepsilon_{S I}$, standard algebraic calculations show the social imitation multiplier to be equal to $1 /\left(1-\varepsilon_{S I}\right)$. Our point estimates yield a social imitation multiplier for formal bank credit equal to 1.218 , with a $95 \%$ confidence interval of $(1.013,1.529)$. For microfinance our estimate is $1.164(0.977,1.440)$ and for informal lending, $1.201(0.993,1.518)$. The interpretation here is that if, for example, formal bank credit is exogenously introduced to some fraction $x$ of households within a network, peer effects will produce a sequence of imitation such that the equilibrium fraction of formal bank credit within the network will ultimately settle at $1.218 x$.

\section{Conclusion}

Our research indicates the presence of endogenous peer effects in credit access are similar in magnitude to those found in the purchase and ownership of our three benchmark consumer goods: cell phones, televisions, and bicycles. These endogenous peer effects appear to some extent among geographical neighbors, but appear most strongly within church networks among our sample of households in Guatemala. We find wealth and education to be directly correlated 
with ownership of each of our consumer goods, and also to credit access, making formal bank borrowing, and microfinance borrowing more likely.

We believe that these results have implications for the introduction of microfinance in new areas, where we find evidence that endogenous peer effects are significant in its adoption.

Moreover, we calculate elasticities of social imitation that are remarkably similar between formal loans, informal loans, and microfinance. We find that the importance of social networks to the adoption of microfinance is similar in magnitude to other types of credit, and the social network effects that we estimate with different types of credit are within the range of those we estimate for the adoption of new consumer technologies. However, the magnitude of the social network effects we estimate for microfinance is relatively modest, suggesting that there remains a strong role for the promotion of microfinance by institutions themselves.

\footnotetext{
1 "Clinton: Support for Guatemala Was Wrong," Washington Post, March 11, 1999; Page A1

2 That neighbors be closely located to one another was key in our particular context for identifying behavioral transmission through geographic proximity.

${ }^{3}$ The cellular phone companies with largest market shares in the country are Telefónica, Claro, and Tigo.

${ }^{4}$ For the geographical neighbor network, this mean is weighted by distance through our behavioral gravity model.

${ }^{5}$ Although the marginal effect for peer effects for microfinance at the neighborhood level carries an insignificant t-statistic, because the point estimate is nearly identical to that of informal credit, we include it in Table 4.
} 


\section{References}

Basu, Kaushik. (1984). The Less developed Economy: A Critique of Contemporary Theory. London: Blackwell.

Brock, William and Steven Durlauf. (2002). A Multinomial-Choice Model of Neighborhood Effects. American Economic Review Papers and Proceedings, 92(2), 298-303.

Conley, Tim and Christopher Udry. (2008). Learning About a New Technology: Pineapple in Ghana. Forthcoming, American Economic Review.

Conley, Tim and Christopher Udry. (2001). Social Learning Through Networks: The Adoption of New Agricultural Technologies in Ghana. American Journal of Agricultural Economics 83(3), 668-673.

Ellison, Glen and Drew Fudenberg. (1993). Rules of Thumb for Social Learning. Journal of Political Economy 101(4), 612-643.

Fafchamps, Marcel. (2002). Returns to Social Network Capital among Traders. Oxford Economic Papers 55(2), 173-206.

Fafchamps, Marcel. (2000). Ethnicity and Credit in African Manufacturing. Journal of Development Economics, 61(1), 205-235.

Freston, Paul. (2001). Evangelicals and Politics in Asia, Africa, and Latin America. Cambridge, UK: Cambridge University Press.

Garrard-Burnett, Virginia. (2000). On Earth as It Is In Heaven: Religion in Modern Latin America. Deleware: A Scholarly Resources Inc.

Kremer, Michael, and Edward Miguel. (2003). Networks, Social Learning, and Technology Adoption: The Case of De-worming Drugs in Kenya. Working Paper, Harvard University and the University of California at Berkeley.

Manski, Charles. (1993). Identification of Endogenous Social Effects: the Reflection Problem. Review of Economic Studies, 60, 531-542. 
Manski, Charles. (1995). Identification Problems in the Social Sciences. Cambridge: Harvard University Press.

McMillan, John, and Christopher Woodruff. (1999). Interfirm Relationships and Informal Credit in Vietnam. Quarterly Journal of Economics, 114(4), 1285-1320.

Microcredit Summit. (2007). http://www.microcreditsummit.org

Munshi, Kaivan and Jacques Myaux. (2006). Social Norms and the Fertility Transition. Journal of Development Economics 80(1), 1-38.

Okten, Cagla and Osilis, Una Okonkwo. (2004). Social Networks and Credit Access in Indonesia. World Development, 32(7), 1225-1246.

Udry, Christopher. (1994). Risk and Insurance in a Rural Credit Market: An Empirical Investigation in Northern Nigeria. Review of Economic Studies, 61(3), 495-526.

Woolcock, Michael and Deepa Narayan. (2000). Social Capital: Implications for Development, Research, and Policy. World Bank Research Observer, 15(2), 225-249.

Young, Peyton. (1998). Individual Strategy and Social Structure: An Evolutionary Theory of Institutions. Princeton: Princeton University Press. 
Table 1: Descriptive Statistics by Village

(Means and Standard Deviations)

\begin{tabular}{|c|c|c|c|c|c|c|}
\hline $\begin{array}{l}\text { Variable } \\
\text { Number of Observations: }\end{array}$ & $\begin{array}{l}5 \text { Villages } \\
464\end{array}$ & $\begin{array}{c}\text { Argueta } \\
95 \\
\end{array}$ & $\begin{array}{c}\text { Cruz-B } \\
50 \\
\end{array}$ & $\begin{array}{c}\text { San Juan } \\
107 \\
\end{array}$ & $\begin{array}{c}\text { Sta. Clara } \\
128 \\
\end{array}$ & $\begin{array}{c}\text { Tzucubal } \\
87 \\
\end{array}$ \\
\hline Education level (years) & $\begin{array}{c}2.6601 \\
(3.04)\end{array}$ & $\begin{array}{c}3.9468 \\
(3.47)\end{array}$ & $\begin{array}{l}1.7959 \\
(2.38)\end{array}$ & $\begin{array}{l}2.6075 \\
(3.17)\end{array}$ & $\begin{array}{c}2.9921 \\
(3.03)\end{array}$ & $\begin{array}{l}1.2771 \\
(1.77)\end{array}$ \\
\hline Age & $\begin{array}{c}36.6205 \\
(13.58)\end{array}$ & $\begin{array}{c}39.6484 \\
(13.05)\end{array}$ & $\begin{array}{c}37.7234 \\
(14.54)\end{array}$ & $\begin{array}{c}37.1700 \\
(12.36)\end{array}$ & $\begin{array}{c}36.1240 \\
(14.84)\end{array}$ & $\begin{array}{l}32.642 \\
(12.33)\end{array}$ \\
\hline Wealth proxy ${ }^{1}$ & $\begin{array}{c}0.4286 \\
(0.17)\end{array}$ & $\begin{array}{c}0.4415 \\
(0.17)\end{array}$ & $\begin{array}{c}0.3678 \\
(0.10)\end{array}$ & $\begin{array}{l}0.3566 \\
(0.14)\end{array}$ & $\begin{array}{c}\mathbf{0 . 4 8 7 1} \\
(0.18)\end{array}$ & $\begin{array}{c}0.4527 \\
(0.18)\end{array}$ \\
\hline Leaders (on vill. committee) & $\begin{array}{c}0.0582 \\
(0.23)\end{array}$ & $\begin{array}{c}\mathbf{0 . 1 3 6 8} \\
(0.35)\end{array}$ & $\begin{array}{c}0.0400 \\
(0.20)\end{array}$ & $\begin{array}{c}0.0000 \\
0.00\end{array}$ & $\begin{array}{c}0.0310 \\
(0.17)\end{array}$ & $\begin{array}{c}0.0964 \\
(0.30)\end{array}$ \\
\hline Evangelical protestants & $\begin{array}{c}0.5323 \\
(0.50)\end{array}$ & $\begin{array}{c}\mathbf{0 . 6 6 3 2} \\
(0.48)\end{array}$ & $\begin{array}{c}0.3800 \\
(0.49)\end{array}$ & $\begin{array}{c}0.4486 \\
(0.50)\end{array}$ & $\begin{array}{c}0.5736 \\
(0.50)\end{array}$ & $\begin{array}{c}0.5181 \\
(0.50)\end{array}$ \\
\hline Tzutujil speaker & $\begin{array}{c}0.2306 \\
(0.42)\end{array}$ & $\begin{array}{c}0.0000 \\
0.00\end{array}$ & $\begin{array}{c}0.0000 \\
0.00\end{array}$ & $\begin{array}{c}1.0000 \\
0.00\end{array}$ & $\begin{array}{c}0.0000 \\
0.00\end{array}$ & $\begin{array}{c}0.0000 \\
0.00\end{array}$ \\
\hline Own Television & $\begin{array}{c}0.4935 \\
(0.50)\end{array}$ & $\begin{array}{c}0.7579 \\
(0.43)\end{array}$ & $\begin{array}{l}\mathbf{0 . 7 0 1} \\
(0.46)\end{array}$ & $\begin{array}{c}0.4245 \\
(0.50)\end{array}$ & $\begin{array}{c}0.3984 \\
(0.49)\end{array}$ & $\begin{array}{c}0.3012 \\
(0.46)\end{array}$ \\
\hline Own cell phone & $\begin{array}{c}0.0931 \\
(0.29)\end{array}$ & $\begin{array}{c}0.1684 \\
(0.38)\end{array}$ & $\begin{array}{c}\mathbf{0 . 1 8 0 0} \\
(0.39)\end{array}$ & $\begin{array}{c}0.0849 \\
(0.28)\end{array}$ & $\begin{array}{c}0.0546 \\
(0.23)\end{array}$ & $\begin{array}{c}0.0241 \\
(0.15)\end{array}$ \\
\hline Own bicycle & $\begin{array}{c}0.3369 \\
(0.47)\end{array}$ & $\begin{array}{c}\mathbf{0 . 6 7 3 7} \\
(0.47)\end{array}$ & $\begin{array}{c}0.5800 \\
(0.50)\end{array}$ & $\begin{array}{c}0.1215 \\
(0.33)\end{array}$ & $\begin{array}{c}0.2265 \\
(0.42)\end{array}$ & $\begin{array}{c}0.2530 \\
(0.44)\end{array}$ \\
\hline Formal bank loan & $\begin{array}{c}0.0495 \\
(0.05)\end{array}$ & $\begin{array}{c}\mathbf{0 . 0 9 6 7} \\
(0.06)\end{array}$ & $\begin{array}{l}0.0370 \\
(0.013)\end{array}$ & $\begin{array}{c}0.0190 \\
(0.0006)\end{array}$ & $\begin{array}{c}0.0535 \\
(0.05)\end{array}$ & $\begin{array}{c}0.0362 \\
(0.01)\end{array}$ \\
\hline Microfinance loan & $\begin{array}{c}0.2515 \\
(0.16)\end{array}$ & $\begin{array}{c}0.1983 \\
(0.22)\end{array}$ & $\begin{array}{c}0.1925 \\
(0.09)\end{array}$ & $\begin{array}{c}0.2397 \\
(0.10)\end{array}$ & $\begin{array}{c}\mathbf{0 . 3 1 5 3} \\
(0.18)\end{array}$ & $\begin{array}{c}0.2640 \\
(0.04)\end{array}$ \\
\hline Informal credit & $\begin{array}{c}0.0732 \\
(0.07)\end{array}$ & $\begin{array}{c}\mathbf{0 . 1 3 3 7} \\
(0.09)\end{array}$ & $\begin{array}{l}0.0618 \\
(0.032)\end{array}$ & $\begin{array}{c}0.0259 \\
(0.0036)\end{array}$ & $\begin{array}{c}0.0785 \\
(0.07)\end{array}$ & $\begin{array}{c}0.0636 \\
(0.03)\end{array}$ \\
\hline
\end{tabular}


Table 2: Cell Phone, Television, and Bicycle Ownership: Endogenous, Contextual, and Correlated Effects--Logit Estimations

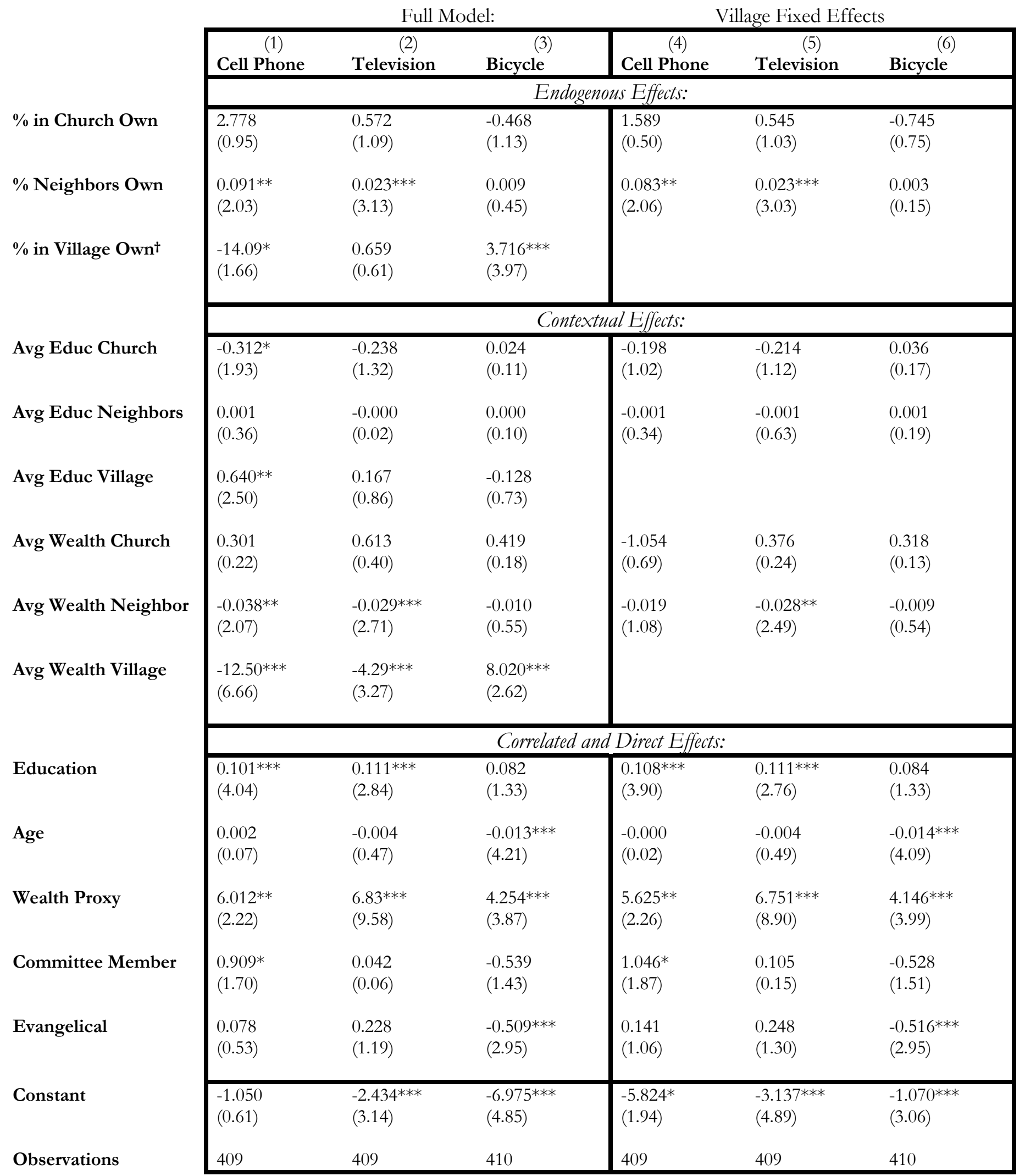

logit coefficients, $t$-statistics in parentheses calculated from village-level clustered standard errors

$*$ significant at $10 \%$; ** significant at $5 \%$; $* * *$ significant at $1 \%$; $†$ may also capture correlated effects. 
Table 3: Type of Credit Access:

\section{Endogenous, Contextual, and Correlated Effects}

Multinomial Logit Estimations

\begin{tabular}{|c|c|c|c|c|c|c|}
\hline & \multicolumn{3}{|c|}{ Full Model } & \multicolumn{3}{|c|}{ Village Fixed Effects } \\
\hline & $\begin{array}{c}(1) \\
\text { Bank }\end{array}$ & $\begin{array}{c}(2) \\
\text { Microfinance }\end{array}$ & $\begin{array}{c}(3) \\
\text { Informal }\end{array}$ & $\begin{array}{c}(4) \\
\text { Bank }\end{array}$ & $\begin{array}{c}(5) \\
\text { Microfinance }\end{array}$ & $\begin{array}{c}(6) \\
\text { Informal }\end{array}$ \\
\hline & \multicolumn{6}{|c|}{ Endogenous Effects: } \\
\hline$\%$ in Church Bank Credit & $\begin{array}{l}4.562 * * * \\
(4.90)\end{array}$ & $\begin{array}{l}5.564^{* * *} \\
(6.15) \\
\end{array}$ & $\begin{array}{l}0.254 \\
(0.13)\end{array}$ & $\begin{array}{l}3.563^{* * *} \\
(3.68)\end{array}$ & $\begin{array}{l}5.256^{* * *} \\
(3.75)\end{array}$ & $\begin{array}{l}1.253 \\
(0.19)\end{array}$ \\
\hline$\%$ in Church MFI Credit & $\begin{array}{l}-2.627 \\
(1.44)\end{array}$ & $\begin{array}{l}1.405^{* * * *} \\
(6.86)\end{array}$ & $\begin{array}{l}-0.177 \\
(0.06) \\
\end{array}$ & $\begin{array}{l}-2.057 \\
(0.93)\end{array}$ & $\begin{array}{l}1.200^{* * *} \\
(8.56)\end{array}$ & $\begin{array}{l}-0.937 \\
(0.31) \\
\end{array}$ \\
\hline$\%$ in Church Informal Credit & $\begin{array}{l}3.364 * \\
(1.94)\end{array}$ & $\begin{array}{l}-9.92^{* * *} \\
(3.47)\end{array}$ & $\begin{array}{l}12.02 * * * \\
(6.19)\end{array}$ & $\begin{array}{l}2.232^{* *} \\
(2.55)\end{array}$ & $\begin{array}{l}-8.71 * * * \\
(3.78)\end{array}$ & $\begin{array}{l}8.267^{* * *} \\
(2.78)\end{array}$ \\
\hline Neighbors Bank Credit & $\begin{array}{l}-0.028 \\
(0.65)\end{array}$ & $\begin{array}{l}0.020^{* * *} \\
(3.28)\end{array}$ & $\begin{array}{l}-0.187 \\
(1.57)\end{array}$ & $\begin{array}{l}-0.096 \\
(1.41)\end{array}$ & $\begin{array}{l}0.020^{* * * *} \\
(2.98)\end{array}$ & $\begin{array}{l}-0.45^{* * *} \\
(2.80)\end{array}$ \\
\hline Neighbors MFI Credit & $\begin{array}{l}0.061^{* * *} \\
(3.51)\end{array}$ & $\begin{array}{l}0.020 \\
(0.55)\end{array}$ & $\begin{array}{l}0.119^{* * *} \\
(3.38)\end{array}$ & $\begin{array}{l}0.075^{* * *} \\
(2.63)\end{array}$ & $\begin{array}{l}0.024 \\
(0.80)\end{array}$ & $\begin{array}{l}0.192^{* * *} \\
(3.61)\end{array}$ \\
\hline Neighbors Infor. Credit & $\begin{array}{l}0.023 \\
(0.37)\end{array}$ & $\begin{array}{l}-0.056 \\
(0.84)\end{array}$ & $\begin{array}{l}0.108^{* *} \\
(2.41)\end{array}$ & $\begin{array}{l}-0.090 \\
(1.18)\end{array}$ & $\begin{array}{l}-0.044 \\
(0.54)\end{array}$ & $\begin{array}{l}-0.05^{* * *} \\
(4.49)\end{array}$ \\
\hline$\%$ Village Bank Credit ${ }^{\dagger}$ & $\begin{array}{l}-53.62^{* *} \\
(2.26)\end{array}$ & $\begin{array}{l}-53.01 * \\
(1.79)\end{array}$ & $\begin{array}{l}377.2^{* * *} \\
(3.97)\end{array}$ & & & \\
\hline$\%$ Village MFI Credit ${ }^{\dagger}$ & $\begin{array}{l}-2.319^{* *} \\
(2.42)\end{array}$ & $\begin{array}{c}-0.799 \\
(0.28)\end{array}$ & $\begin{array}{l}18.01^{* * * *} \\
(3.02)\end{array}$ & & & \\
\hline \multirow[t]{2}{*}{$\%$ Village Informal Credit ${ }^{\dagger}$} & $\begin{array}{l}30.584^{*} \\
(1.95)\end{array}$ & $\begin{array}{l}34.064 \\
(1.22)\end{array}$ & $\begin{array}{l}-205.1^{* *} \\
(3.92)\end{array}$ & & & \\
\hline & \multicolumn{6}{|c|}{ Contextual Effects: } \\
\hline Avg Education --Church & $\begin{array}{l}-0.321 \\
(1.22)\end{array}$ & $\begin{array}{l}0.245 \\
(1.21)\end{array}$ & $\begin{array}{l}-0.002 \\
(0.01)\end{array}$ & $\begin{array}{l}-0.508^{* *} \\
(2.32)\end{array}$ & $\begin{array}{l}0.121 \\
(0.43)\end{array}$ & $\begin{array}{l}-0.555^{*} \\
(1.87)\end{array}$ \\
\hline Avg Education--Neighbor & $\begin{array}{l}-0.006 \\
(1.48)\end{array}$ & $\begin{array}{l}0.001 \\
(0.32)\end{array}$ & $\begin{array}{l}0.002 \\
(0.63)\end{array}$ & $\begin{array}{l}-0.006 \\
(1.29)\end{array}$ & $\begin{array}{l}0.001 \\
(0.75)\end{array}$ & $\begin{array}{l}0.014^{* * * *} \\
(9.23)\end{array}$ \\
\hline Avg Education --Village & $\begin{array}{l}0.180 \\
(0.45)\end{array}$ & $\begin{array}{l}1.467^{* * *} \\
(7.80)\end{array}$ & $\begin{array}{l}-3.49^{* * *} \\
(3.08)\end{array}$ & & & \\
\hline Avg Wealth--Church & $\begin{array}{l}3.312^{* *} \\
(2.26)\end{array}$ & $\begin{array}{l}-3.155^{* *} \\
(2.43)\end{array}$ & $\begin{array}{l}1.859 \\
(0.90)\end{array}$ & $\begin{array}{l}4.598^{* * *} \\
(2.90)\end{array}$ & $\begin{array}{l}-2.384 \\
(1.19)\end{array}$ & $\begin{array}{l}7.46^{* * *} \\
(4.04)\end{array}$ \\
\hline Avg Wealth--Neighbors & $\begin{array}{l}-0.009 \\
(1.15)\end{array}$ & $\begin{array}{l}-0.021 \\
(0.87)\end{array}$ & $\begin{array}{l}-0.05^{* * *} \\
(7.26)\end{array}$ & $\begin{array}{l}-0.005 \\
(0.52)\end{array}$ & $\begin{array}{l}-0.022 \\
(1.20)\end{array}$ & $\begin{array}{l}-0.023^{* * *} \\
(3.97)\end{array}$ \\
\hline \multirow[t]{2}{*}{ Avg Wealth--Village } & $\begin{array}{l}0.493 \\
(0.10)\end{array}$ & $\begin{array}{l}-14.9^{* * *} \\
(2.60)\end{array}$ & $\begin{array}{l}-33.2^{* * * *} \\
(2.86)\end{array}$ & & & \\
\hline & \multicolumn{6}{|c|}{ Correlated and Direct Effects: } \\
\hline Education & $\begin{array}{l}0.198^{* * * *} \\
(3.79)\end{array}$ & $\begin{array}{l}0.149 * * * \\
(5.23)\end{array}$ & $\begin{array}{l}0.032 \\
(0.31)\end{array}$ & $\begin{array}{l}0.182^{* * *} \\
(2.92)\end{array}$ & $\begin{array}{l}0.155^{\text {*** }} \\
(4.98)\end{array}$ & $\begin{array}{l}0.024 \\
(0.23)\end{array}$ \\
\hline Age & $\begin{array}{l}-0.050^{* *} \\
(2.00)\end{array}$ & $\begin{array}{l}-0.020 \\
(0.85)\end{array}$ & $\begin{array}{l}0.011 \\
(0.63)\end{array}$ & $\begin{array}{l}-0.047 \\
(1.64)\end{array}$ & $\begin{array}{l}-0.021 \\
(0.87)\end{array}$ & $\begin{array}{l}0.017 \\
(0.86)\end{array}$ \\
\hline Wealthproxy & $\begin{array}{l}2.691 \\
(1.25)\end{array}$ & $\begin{array}{l}2.259^{* * *} \\
(3.92)\end{array}$ & $\begin{array}{l}-1.532 \\
(0.99)\end{array}$ & $\begin{array}{l}2.259 \\
(0.97)\end{array}$ & $\begin{array}{l}1.907 * * \\
(2.55)\end{array}$ & $\begin{array}{l}-0.434 \\
(0.23)\end{array}$ \\
\hline Committee & $\begin{array}{l}0.674 \\
(0.66)\end{array}$ & $\begin{array}{l}1.842^{* * *} \\
(3.97)\end{array}$ & $\begin{array}{l}0.610 \\
(0.85)\end{array}$ & $\begin{array}{l}0.869 \\
(0.98)\end{array}$ & $\begin{array}{l}1.874 * * * \\
(4.08)\end{array}$ & $\begin{array}{l}1.821 \\
(1.52)\end{array}$ \\
\hline Evangelical & $\begin{array}{l}0.120 \\
(0.16)\end{array}$ & $\begin{array}{l}0.505^{* * *} \\
(3.07)\end{array}$ & $\begin{array}{l}0.335 \\
(0.53)\end{array}$ & $\begin{array}{l}0.078 \\
(0.10)\end{array}$ & $\begin{array}{l}0.469^{* *} \\
(2.50)\end{array}$ & $\begin{array}{l}0.193 \\
(0.45)\end{array}$ \\
\hline Constant & $\begin{array}{l}-2.964 \\
(1.24)\end{array}$ & $\begin{array}{l}0.493 \\
(0.19)\end{array}$ & $\begin{array}{l}10.279 * \\
(1.74)\end{array}$ & $\begin{array}{l}-2.48^{* * *} \\
(0.613)\end{array}$ & $\begin{array}{l}-1.32^{* * *} \\
(11.48)\end{array}$ & $\begin{array}{l}-10.124 \text { *** } \\
(5.46)\end{array}$ \\
\hline Observations & 411 & 411 & 411 & 411 & 411 & 411 \\
\hline
\end{tabular}

Logit coefficients, $t$-statistics in parentheses calculated from village-level clustered standard errors

* significant at $10 \%$; ** significant at $5 \%$; *** significant at $1 \%$; $\dagger$ may also capture correlated effects. 
Table 4: Estimated Elasticities of Social Imitation

\begin{tabular}{|l|ccc|ccc|}
\hline & \multicolumn{3}{|c|}{ Consumer Good: } & \multicolumn{3}{c|}{ Credit Source: } \\
\cline { 2 - 6 } Network: & Cell Phone & Television & Bicycle & Bank & Microfinance & Informal \\
Church & $0.0954^{\dagger}$ & $0.143^{\dagger}$ & - & $0.179 * *$ & $0.141 *$ & $0.167^{* *}$ \\
Neighborhood & $0.125^{*}$ & $0.255+t$ & - & - & 0.0478 & $0.0552+t$ \\
Village & - & - & - & - & - & - \\
\hline tmarginal coefficient significant only at 25-29\% level; +t marginal coefficient significant only at 13-19\% level. \\
*marginal coefficient significant at 10\%; **marginal coefficient significant at 5\%; ***marginal coefficient significant at $1 \%$. \\
\hline
\end{tabular}

Figure 1: Survey Area

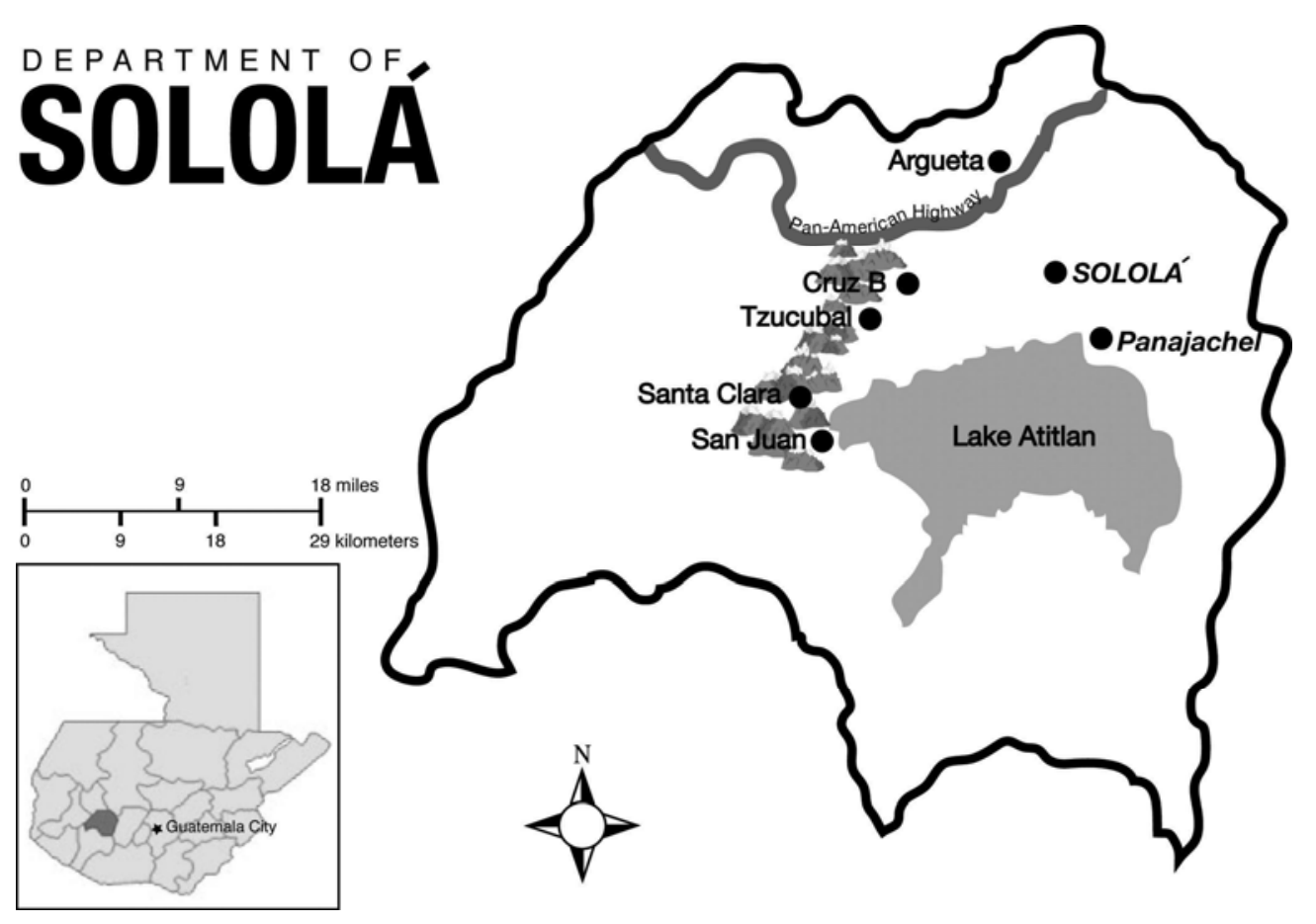

